\title{
Short biographies of the main characters
}

Gladys Cox: Born in 1892. Medical officer at the Walworth Women's Welfare Centre. Member of the National Birth Control Association, the Society for the Study and Promotion of Family Hygiene, and the Birth Control Investigation Committee. Author of Clinical Contraception.

Sylvia Dawkins: Born in 1904 and qualified in 1929. She left general practice to work in a family planning clinic in 1948. Medical officer of the Islington Family Planning Clinic and clinical assistant at the dyspareunia and fertility clinic, University College Hospital, London. Became a group leader in psychosexual counselling. She died in 1995.

Frances Huxley: Born in 1885 and qualified in 1908. She was a gynaecological surgeon at the Marie Curie Hospital and founding member of the Medical Women's Federation (MWF), serving as the London president in 1928. In 1929, she was elected as a Foundation Fellow of the Royal College of Obstetricians and Gynaecologists. She participated in the Fifth International Neo-Malthusian and Birth Control Conference in 1922, and was the first British woman doctor to present her work on contraception.

Dr Margaret Jackson: Born in 1898. Founding member and medical officer of the Exeter and District Women's Welfare Centre. Member of the medical committee of the Family Planning Association (FPA). She specialised in infertility and artificial insemination, and helped many couples to have children. She wrote extensively on the subject. Jackson also carried out clinical trials on intrauterine devices (IUDs), and her centre became one of the four international centres collecting data on this form of contraception. 
Dr Mary Macaulay: Mary Macaulay was medical officer of the Liverpool branch of the FPA between 1930 and 1956, and a marriage guidance counsellor. She wrote The Art of Marriage.

Joan Malleson: Born in 1899. Qualified in 1926. She had her own private practice and, alongside it, worked in a family planning clinic. Specialising in contraception and sexual difficulties, she was a member of the executive committee of the National Birth Control Association. For several years, Malleson was in charge of a clinic for difficulties with marital adjustment, which later became a clinic for sexual difficulties, at the North Kensington Women's Welfare Centre. In 1950, she was appointed head of the contraceptive clinic at University College Hospital. A member of the Labour Party and the Eugenics Society, she supported the Abortion Law Reform Association. She also wrote several manuals on contraception and sexual difficulties, and leaflets for the Family Planning Association. Malleson died in 1956.

Prudence Tunnedine: Born in 1928, she studied medicine at Guy's Hospital, qualifying in 1953. She worked in family planning clinics and became specialised in sexual counselling. She was a founding member of the Institute of Psychosexual Medicine.

Helena Wright: Born in 1887. Qualified in 1915. In 1921, she went to China as an associate professor of gynaecology at the Shandong Christian University, returning to England in 1928. She joined the National Birth Control Association and the Birth Control Investigation Committee, and held the post of chief medical officer at the North Kensington Women's Welfare Centre (1930-60). Wright was a founding member of the International Planned Parenthood Federation (IPPF) in 1952, and served as both treasurer and chair on the IPPF's medical committee. She published extensively on the subject of sex in marriage. 